\title{
going nowhere? \\ the Politics of Remembering (and \\ Forgetting) Molly Ringwald CHRISTINA LEE
}

\section{Don't you forget about me \\ Don't, don't, don't, don't. ${ }^{1}$ \\ Simple Minds}

Each generation is remembered via seminal icons seen to embody the 'essence' of an era, with youth culture contributing an impressive catalogue of key personalities. The canonised likes of James Dean, Elvis Presley and Marlon Brando continue to be memorialised and shrouded in a cloak of mystery, romantic tragedy and myth; with books, movies and television programs functioning as a type of prolonged eulogy to the dead and buried. While they have entered history as notable figures, this paper takes as its subject American film actor and youth icon Molly Ringwald who is of the present but remains firmly, and problematically, entrenched in the past. Under the auspices of filmmaker John Hughes, Ringwald would be hailed as the quintessential teen queen in the mid-1980s. By the time her face graced the front page of a 1986 edition of Time magazine, she was already a household name for a market that crowned her the 'model modern teen' and the poster child for teenage angst. ${ }^{2}$ During her three year reign at the multiplex, the Molly Ringwald phenomenon instigated a media feeding frenzy and spilled onto the streets with devoted fans, the Ringlets, imitating Ringwald's punk-flapper fashion and flaming mop top. Ringwald's fame began to descend into obscurity in the late 1980s which coincided with her attempt at breaking into what many considered more adult roles. While it may appear a case of yet another child actor's unsuccessful transition to adulthood—-their novelty and endearing cuteness having worn thin—Ringwald continues to be prolific in film, television and stage productions and has achieved considerable 
acclaim; even appearing in Jean Luc-Godard's 1987 film adaptation of King Lear. However, there remains the incessant need to situate the actor in a 1980s time capsule. I argue that this nostalgic fixation with Ringwald as the eternal youth and association with the decade is symptomatic of contemporary preoccupations and anxieties in which the past is understood "not as a given "thing" which we must preserve, but as a force constantly resonating in the present, producing new layers of sound and meaning. ${ }^{3}$ Where is Molly Ringwald now? And does anyone really care?

The fear of being forgotten is perhaps matched only by the paralysing anxiety of being trapped in the past and unable to escape. As an ideological compression of events, it is history at its most efficient and ruthless. History positions the temporal and spatial into orderly compartments where it 'clarifies, tidies, and elucidates'. ${ }^{4}$ What is inevitably lost in this lockdown is the fundamental basis of time, that is, the intensity of the ephemeral. As history handles excess awkwardly, it often replaces the liminality and emotive gravity of an experience with measurable facts and figures, especially those that do not fall into the category of official history. In its fixed state, authorised narratives occupy the centre while marginalised narratives are ignored or pushed so far to the edges that they disappear altogether. In studying the cultural body of Ringwald - a figure who is regularly exhumed from a nostalgic necropolis in popular remembrances - the broader scope of the paper extends beyond a case study of a particular screen icon to broach the politics of memory and history in the context of youth cinema, and the role of film in facilitating the restoration of what history has omitted.

\section{— Exhuming the past AND historical in(ter)Vention}

Zygmunt Bauman states, 'Identity sprouts on the graveyard of communities, but flourishes thanks to the promise of the resurrection of the dead'. ${ }^{5}$ This resurrection conjures up the ghosts of that which reiterate and reinstate dominant histories. The social relevance bestowed upon an event, a period, a people, becomes incumbent upon its ability to be defined via the tangible artefacts and verifiable information encased in books, museum exhibits, documents and the records from authority figures and dignitaries - an archival history if you will. The result is an often static and petrified narrative permanently etched in relics and monuments, stored in dusty vaults where the clock has stopped. Problematically, this creates 'refugees, displaced persons, men and women without a country, cast out of time, the living dead' whose experiences are erased the very moment they are surpassed by the chronometer of modernity. ${ }^{6}$ By relegating their subsistence to the domains of myth, heresy, rumour, fiction and folklore, this leaves little or no vestige of their existence. One need only turn to political demonstrations, such as co-ordinated protests against the Iraq war and refugee detention centres, to witness the privileging of sanctioned government and media reports, even when factually incorrect, over public opinion and even the experiences of those involved in the 
actual event. The inability to anchor an identity to a validated past writes out disempowered groups from their own histories, perpetuating their dislocation from the social memoryscape.

Alternative and oppositional narratives and ideologies are to be found in other forms such as oral history, and in popular or mass mediums. ${ }^{7}$ These modes expand the possibilities of (re)thinking about the past, and contribute to a collective process that can be described as the 'social production of memory' where everyone is a potential historian. ${ }^{8}$ Cinema provides one such implement for recording (and later recalling) events that may otherwise be ignored. Considering the visual and aural spectacle of youth culture, it is of little surprise that cinema has become integral in providing a kind of unofficial documentation of the youth experience with its ability to capture sight, sound and movement. More importantly, it is the affective threads in cinema-its ability to respark certain corporeal responses-that reconnects the past to the present tense and creates not only meaning, but furthermore a sense of meaningfulness. The diegesis of film bestows youth a time and space which can be named and claimed as their own by performing the roles of subordination, dominance and struggle that speaks in the literacy of the disempowered. As Patrick Wright asserts, it is the periphery 'where the disorders of the centre are most manifest and ... where the future must be found'.${ }^{9}$ Here, the stories of the unpopular players in a history not of their own making become salient and purposeful. When a fashion, the graffiti on a wall, the local street-corner hangout or the parochial colloquialism associated with a fad means more than the contents of a published register of events and invokes a collective consciousness, then the rules of coercive interplay between history and identity begin to buckle under the weight of memories liberated from the past.

Too often has history been equated solely with a complete, and inert past and unquestioned truth. Time is tidily categorised as past, present and future in dominant historiography; separate checkpoints on a disconnected overpass. History creates the illusion of objectivity, stability and distance that maps a 'symbolically serviceable past' that allows us to derive an explanation of where we are now, the final destination, in a linear and naturally unfolding narrative. ${ }^{10}$ The paradox is 'that the proper object of history is not the past but the past-present relationship'. ${ }^{11}$ The interstices between past-present become an ambiguous space where memory and nostalgia hover, regarded as an offence to the empirical logic of archival records with its exactitude of dates, key figures and locations of importance. As argued by Andreas Huyssen, however, it is precisely this fissure in time that makes memory powerfully alive and critical in our understandings of the past. ${ }^{12}$ The image banks of bygone days do not function as storage systems or passive receptacles, but rather partake in the dynamic, reciprocal shaping of current times. ${ }^{13}$

Popular memory is one means of investing the past in the present. It retrieves throwaway slivers from what Greil Marcus describes as 'the dustbin of history', that is, alternative stories, 
flows of time and space which elucidate the struggles and paradoxes that shape social organisation and knowledge, and challenge the notion of a monopolistic, singular remembering. ${ }^{14}$ The bridging of gaps reinserts those made 'invisible, silent, or despised' by modernity into the landscape of the Now, thus providing the opportunity to revise, rewrite and reinterpret previously untouchable truths of societal antiquity generated by (oftentimes nationalist) myth. ${ }^{15}$ Popular memory is both an object of study and a political practice. ${ }^{16}$ It enables the disenfranchised to negotiate an identity from their fragmented and fractured subjectivities and to intervene in historical narrative. ${ }^{17}$ Svetlana Boym's concept of reflective nostalgia is worthwhile considering here as an adjunct to popular memory. Boym contends that while restorative nostalgia evokes national narratives through a return to origins and intentional monuments which attempt to recuperate a sense of historical truth, reflective nostalgia is more concerned with the 'mediation on history and passage of time' and the 'imperfect process of remembrance'. ${ }^{18}$

If restorative nostalgia ends up reconstructing emblems and rituals of home and homeland in an attempt to conquer and spatialize time, reflective nostalgia cherishes shattered fragments of memory and temporalizes space. Restorative nostalgia takes itself dead seriously. Reflective nostalgia, on the other hand, can be ironic and humorous. It reveals that longing and critical thinking are not opposed to one another, as affective memories do not absolve one from comparison, judgment or critical reflection. ${ }^{19}$

Popular memory and reflective nostalgia wedge the past into the discursive and ideological framework of the present in which remembering becomes political. They fill in the holes in official historiography, where the adage of 'gone but not forgotten' holds steadfast. In making this statement, it is important to point out that both are hegemonic enterprises: like history, they are intrinsically interlocked in constant negotiation with dominant discourses and also seek validation and a legitimate status. This does not negate their significance as historical interventions but provides the opportunity for critical reflection.

\section{— Remembering Molly: MOving Memories}

Molly Ringwald, in collaboration with John Hughes (in varying capacities of director, producer and scriptwriter), churned out in succession three seminal films about and for youthSixteen Candles (1984), The Breakfast Club (1985) and Pretty in Pink (1986). Sixteen Candles was the simple story of a girl whose sixteenth birthday is forgotten by her family. It proved hugely successful financially and marked Ringwald's debut into teendom in the lead role as the distraught Samantha Baker. The story of misunderstood youth struck an emotional chord with its primarily teenage viewership which secured an audience for Hughes' future projects 
and accorded Ringwald instant fame. ${ }^{20}$ As a consummate performer, she was metamorphosed into an adolescent ingénue whose name alone became a 'bankable box-office attraction'. ${ }^{21}$

The second film, The Breakfast Club, took as its premise a torturously boring day of Saturday detention that brought together five students from the separate echelons of the high school hierarchy. The tropes of the 'brain, an athlete, a basket case, a princess and criminal', as defined by one of the principal characters in the film, are interrogated and deconstructed. By the film's conclusion, each character has undergone a life-altering revelation of the injustices of social stereotyping and confronted their own inadequacies. As the prom queen Claire Standish, Ringwald's portrayal of simultaneous vulnerability and stoicism solidified her as an icon of her times (and age). The Breakfast Club's welcomed reception hailed a rising generation of talented actors dubbed the Brat Pack, but also testified to the dynamism of the Hughes-Ringwald partnership.

The last of the triptych was Pretty in Pink; the vehicle to showcase Ringwald's acting prowess and celebrity power. Although promotional material alluded to the on-screen chemistry of the trio comprised of Ringwald, Andrew McCarthy and Jon Cryer in the roles of Andie, Blane and Duckie respectively, it was Ringwald's name in the credits that drew the crowds and her performance that became synonymous with the film. As a student from a blue-collar background situated at the lower rungs of the social pecking order, Ringwald's character continued to demonstrate stubborn determination, confusion and optimism that had become her trademark range of emotions in the Hughes oeuvre. The trials and tribulations of being young attained a sense of seriousness and validity that had been immortalised in the 1950s films of James Dean, but had become somewhat diluted with a spate of late 1970s and early 1980s 'gross-out' predecessors such as National Lampoon's Animal House (1978) and Porky's (1982). The 1980s would witness a boom in the genre of youth cinema, and it is no exaggeration to claim that Hughes lead, and rose above, the pack. As Stephen Tropiano comments, Hughes 'set the tone for the eighties teen films'. ${ }^{22}$ The auteur would be known for his 'deft touch for teens' cultural concerns and personal interests' and his ability to convey the dimensions and depth of his subjects. ${ }^{23}$ Hughes made six teen films in the decade of which three starred Ringwald as the leading actor.

The moral centres of the Hughes-Ringwald films addressed the insecurities associated with teen life. They juxtaposed the struggling working class with the progeny of wealthy Baby Boomers and explored the guilt and pain associated with hallway harassment. The movies presented a mixture of the innocence and craziness typical of the genre, grounded in the very real experiences of 'teendom's silent majority of average, middle-class suburban kids'. ${ }^{24}$ The actors were propelled into the public sphere as archetypal teenagers, enabling Ringwald to reach the pinnacle of her popularity. She was not an untouchable figure that 
young people merely emulated or desired, but rather emanated a 'charismatic normality'. ${ }^{25}$ Ringwald's stardom is a phenomenon of production (a filmic construction) and consumption by the viewship. Ringwald's characters are markedly different in her three Hughes films (a disgruntled and cynical sixteen year old, an uptown preppie and a working-class loner) and each movie is distinctive in terms of genre (Sixteen Candles is outrageous screwball comedy, Pretty in Pink falls into the category of 'serious drama' and The Breakfast Club vacillates between the two). However, there are common threads running through all the movies which are necessarily 'broadly the same in order to permit recognition and identification'. ${ }^{26}$ One of these was the vulnerability of her characters which was capitalised on through narrative and aesthetics of film style, such as the camera's lingering close-ups which privileged moments of pensive contemplation and confusion as conveyed through Ringwald's signature pout and elfish facial expressions. The films additionally offered quasi-utopian resolutions to teen existential crises-being ignored on one's sixteenth birthday, the dream of seemingly impossible romances, being misunderstood, and a quest for self identity. Herein lies the glue that bonds Ringwald with not only her ardent fans, but also to an audience of youth who experienced the 1980s wave of American teen cinema. Ringwald's charisma is derived from her ordinariness-there is nothing remarkable or spectacular about the situations she was in—compared to Weird Science (1985) and Ferris Bueller's Day Off (1986). Coupled with the intensity and intimacy of the big screen, this ordinariness is transformed into something quite extraordinary; an extraordinariness that refers not only to the aura surrounding celebrity status but also the audiences' own startled identification with an actor's performance and familiar scenarios. In Ringwald's characters, youth saw inflections of their own growing pains. At her pinnacle, the actor had become the poster girl for a generation of youth and exerted impressive clout. At eighteen years of age, she had signed a lucrative contract with United Artists that allowed her the virtual freedom for development and creative control of projects. ${ }^{27}$ Sought after by some of the film industry's most influential personalities, it seemed the actor was destined to continue her successful career into the 1990s.

Molly Ringwald could do no wrong, that is, until she grew up. First, she lost her virginity, fell pregnant and then got married. I am referring to the films The Pick Up Artist (1987), For Keeps (1988) and Betsy's Wedding (1990) respectively. Ringwald had matured from young love and prom dresses to dealing with the mafia, battling post-partum depression and wedding gown dramas. Even when still portrayed as a teenager, the roles the actor pursued (dis)located her outside of the insulated high school zone. In Fresh Horses (1988), Ringwald was cast as a teenage bride who engages in an illicit affair with a college student (played by her Pretty in Pink co-star Andrew McCarthy). The setting was a barren, rural wasteland that removed the characters from the familiarity of a pink bedroom or the grand ballroom of the annual prom. 
Ringwald and McCarthy reprise the parts of disadvantaged girl from the wrong side of the tracks and privileged preppie. The film goes so far as to make a direct reference to Pretty in Pink when Matt gives Jewel a pink scarf as a gift. Jewel, however, is not the same sweet sixteen year old that was Samantha Baker. Her backstory reveals the incestuous advances of a drunkard stepfather and a marriage of convenience to a wholly detestable older man. Jewel does not attend school and whittles her days away wandering around dilapidated buildings and sites. Thrust into a premature adulthood, Jewel's experiences and knowledge isolated her from the majority of youths who watched the film. Molly Ringwald was no longer the model teenager.

After Pretty in Pink, Ringwald's films tended to be marginally profitable. None were embraced with the same fervour that had greeted the Hughes-Ringwald repertoire. A bitter parting from Hughes after Pretty in Pink signalled Ringwald's severance of the umbilical cord from the man who had made her the face of misunderstood adolescence in the 1980s; completing the actor's impatience to graduate from the teenage years. ${ }^{28}$ Just as rapidly as her ascension to fame, three years later she was pronounced as past her prime. Ringwald no longer seemed to be making history. She appeared to have become history. In hindsight, the promotional poster slogan for Sixteen Candles: 'It's the time of your life that may last a lifetime' begins to sound like an ominous premonition of arrested adolescence.

There are socio-political implications involved in the rendering and remembering of Molly Ringwald as the personification of an era and society in our private reminiscences and popular culture in which Ringwald's past has been scrawled over the pages of her present to perpetuate a myth of the way things never really were. The actor Sandra Dee provides a useful point of reference in gauging Ringwald's importance as a teen icon as both share several uncanny resemblances. Achieving star status for her roles in clean teenpics (in 1950s-1960s) and most famous for her characters of Gidget and Tammy, Dee was dubbed the 'role model of choice ... "Her wide appeal to her own generation as well as adults doubtless stems from the fact that she seems to epitomize that nice 'girl next door' ... relying on decent instincts and common sense", according to a 1959 popularity poll in Motion Picture Herald. ${ }^{29}$ However, Dee's public image was a well-constructed facade that concealed a traumatic private life scarred by incest from the age of eight, alcoholism, anorexia, ill health and a troubled adulthood. ${ }^{30}$ Even though later films would cast her as the sexual tease or nymphet, the Dee mythology of the chaste adolescent stubbornly persisted even after the actor's personal traumas were leaked into the media. ${ }^{31}$ Roland Barthes' definition of myth as the naturalisation of history through the distortion (not concealment) of the meaning of a sign which is interpreted as the reason, rather than the motive, for an existence is relevant here. ${ }^{32}$ According to Barthes, the 'function of myth is to empty reality: it is, literally, a ceaseless flowing out, a haemorrhage, or perhaps an evaporation, in short a perceptible absence'. ${ }^{33}$ Emptied of meaning, Sandra 
Dee (both person and personality) as signifier was filled with the ambitions and dominant values of a society which prided itself on its new-found stability after World War II. This resolve would only be fortified after the socio-political upheavals in the following two decades that included the turmoil of the Vietnam War, the sexual revolution and the decimated confidence of the American public after the Watergate debacle.

Dee's embodiment of cultural contradictions poses a dilemma that necessitates an airbrushed image of a golden 1950s of drive-in movies and soda fountains. The story of a dysfunctional, middle-aged woman who was lonely, depressed and psychologically damaged has no place in endorsed rememberings. As Boym writes, 'Revelation of mortality is of no use for group identity-it is precisely what has to be suspended' in order to stave off acceptance of 'physical and human frailty, aging and the unpredictability of change'. ${ }^{34}$ Sandra Dee of the Now never existed; replaced by the perpetual image of a beautiful, uncorrupted girl who replays in time like a record on a continuous loop. The all-American sweetheart is a cultural construction which acts as a buffer against the actualities of social malaise and is representative of a symbolically serviceable past. This was astutely articulated by Giorgio Agamben who wrote, 'The real subject of history is the State'. ${ }^{35}$ It was never really about Sandra Dee. Although the actor may have entered anthologies of cinema as a figure of the times, the erecting of a metaphoric memorial of Tammy appears more as an early tombstone in retrospect. Although her career was going somewhere, Dee herself was going nowhere.

Ringwald (similar to Dee) was the vessel for an impossible vision of social order that had already begun to crack during the 1980s and would worsen throughout the 1990s. For instance, where the Yellow Peril once threatened the nation-state, the paranoia of the AIDS epidemic transplanted this terror of invasion onto the individual body. The legacy of political and economic restructuring by the Reagan Administration had fostered an ethos of mass gluttony and fuelled rampant consumerism in the face of societal denigration. ${ }^{36}$ The spiritual emptiness of the 'go-go 80s and dictum that "greed is good"', encapsulated in Oliver Stone's Wall Street (1987), extended beyond the world of executive mergers and acquisitions to deepen into the sanctuary of the family and home. This theme was explored in the timely film adaptation of Bret Easton Ellis' novel Less Than Zero (1987). In arrant contrast to the idealism in Hughes' films, Less Than Zero plunged its youth into a world of opulent Beverly Hills mansions, expensive convertible cars, fatalistic orgies of drugs, meaningless sex and the dark underbelly of gold-cufflink crime. The series 21 Jump Street similarly capitalised upon the fears of the accelerated aging of the young. ${ }^{37}$ The episodes revolved around a team of undercover police officers who infiltrate high schools and colleges by posing as students where they expose all manner of social problems that include narcotics use, homosexual 
bashings, teenage prostitution, gang-related violence and homicide. Youth were no longer in danger, but more likely the ones to be dangerous. The menace had crossed over enemy lines and was now on domestic soil.

As the virtuous teenager in the Hughes oeuvre, Ringwald was the corporeal collateral against the widespread ethos of nihilistic consumption, corruption and hedonism that had become associated with the 1980s. In a time when sexual intercourse ran the risk of disease, emotionless trysts or even death, Ringwald's characters were interested in romantic love and relationships. ${ }^{38}$ In the context of widening disparities between the prosperous few and economically-disadvantaged many, Ringwald's characters reconciled the gaping chasms through social mobility in which 'the mystical prescience of the loser-outsider and her victory over a corrupt and corrupting society, engages a restoration and realization of the American ideal of a classless and egalitarian society'. ${ }^{39}$ When the collapse of the nuclear family continued to burgeon, Ringwald functioned as the unwavering core or a voice of reason. In Sixteen Candles, the chaotic environment of the home differentiates between Samantha's rationalism and her scatter-brained family members as they prepare for her older sister's wedding. In Pretty in Pink, Andie lives with her unemployed father. From the film's onset, she is established as the steady centre of the family and assumes an almost maternal role. It is she who must urge her father to seek work, to accept his wife's desertion several years prior and to meet his responsibilities as a parent. In The Breakfast Club, as the majority of the narrative takes place within the school premises, Claire's interaction with her family is minimal. However, from the brief discussion the character has with her father (Tim Gamble) in the film's opening sequence, he is portrayed as ignorantly detached from his daughter and an unsound authority figure. When Claire complains to him that her consignment to Saturday detention is absurd, Mr Standish retorts: 'I'll make it up to you. Honey, ditching class to go shopping doesn't make you a defective. Have a good day.' The apathetic response is telling. There is no interest, nor time, in listening to the experiences of youth.

\section{— The TIMe of Your Life: STRETCHING THE MOMENT}

The role of cinema in contemporary society is bound to collective consciousness and is able to counteract the disappearance of an experience. This has implications not only for extending the parameters of history but also the notion of time itself and the articulation of cultural spaces. To illustrate this, I turn to Some Kind of Wonderful (1987) which was written by Hughes. The protagonist (Eric Stoltz) expends his college fund savings on a pair of diamond earrings for the most desirable girl at his school after she agrees to accompany him on a date. Keith's father (John Ashton) furiously reprimands his son for this decision and attempts to reduce him to an ignorant teenager. 
Father: You're only eighteen years old for Christ's sake!

Keith: Then I'm nineteen, then I'm twenty. When does my life belong to me? ... See, in the eyes of most people around here, I'm a nothing ... I want to show this girl that I'm as good as anybody else ... Dad, didn't you ever have guys at your school that didn't fit in?

... Well, I'm one of those guys.

Father: I thought things were going okay for you.

Keith: Yeah, well I like art. I work in a gas station. My best friend is a tomboy. These things don't fly too well in the American high school.

The social alienation of the character becomes manifest in his livelihood and leisure. Keith's greasy work overalls and fondness for painting become signifiers of his second-class citizenship and exclusion from the dominant centre of the influential school clique. The oppressive hierarchies between the powerful and marginalised are played out within the realm of the confessional date and popular culture; sites of negotiation and contestation where youth do have a degree of power in effecting change. For Keith, the sensory and emotive assumes a significance more real than the dream of a future manufactured by his father which marks a radical, political agenda to live in the Now. The culmination of teen movies at the all-important keg party, prom, or clandestine rendezvous for the meeting of lovers do not just capture a fleeting moment but a splinter of time that lasts a lifetime because of its gravity. Here, cinema functions as a form of interpretive truth which captures moments, mimicking the candidness of a Polaroid picture. As cultural constructions that blur the boundaries between personal recollection and public knowledge, they investigate 'cultural patterns of fantasy and denial' 40 Popular media and memory reclaim the discredited private and collective sources of information, practices and expressions that are not considered wholly credible and imbibe them with a cultural currency and means of contribution to a historical narrative.

Popular memory gives legitimacy to evanescent moments that are lost in the translation of experience to historiography where there is no adequate, nor appropriate, linguistic modality for its expression. This notion is supported by Stewart Brand's propositions in The Clock of the Long Now. ${ }^{41}$ Brand argues that memory is sensory as it moves faster than our current thoughts can process. As a result, the industrial time imposed on the working body lacks a perfect synchronisation with the temporal that memory imposes on our recollection of events. The Long Now testifies to the mutability of time, its multi-dimensionality and the role of corporeality in its interpretation. Brand's theorisations imply that the relevance of a narrative becomes less contingent upon its correspondence to the actualities of an objective world than upon 'its ability to describe a possible world that one lives and experiences'. ${ }^{42}$ This sensory history permits recollections of the past that need not be merely surgically retrieved from a repository, but is manifested in the physical sensation during the act of recall. The 
seductive myth of history as logically-derived outcomes of past events can no longer displace experience 'as far as possible outside the individual: on to instruments and numbers'. ${ }^{43}$ When it is relocated onto the individual, the authority granted by scientific certainty and verification becomes suspect and accepted truths begin to fray at the edges. When the illusion of a centrifugal stability and hegemonic mask becomes transparent, relations of power are at their most volatile and vulnerable. Popular memory and the cinematic apparatus clearly have significant application for recording and recalling the experiences of youth who have often been deemed unworthy of debate and discussion, with exceptions occurring under highly specific conditions such as tragic dramas and moral panics as illustrated by Rebel Without A Cause (1955), the suicide of Kurt Cobain and the Columbine massacre; and cultural revolutions that include the rave phenomenon and third wave feminism. This raises the question of whose history is really being told and by whom; a sentiment expressed by Jon Savage who wrote, 'there's a whole history being constructed here, but I'm not sure that it's mine'. ${ }^{44}$ The direct transcription of artefact to fact and vice versa cannot always account for the more personalised renditions of an event. A more flexible paradigm that deals with the proto-linguistic must integrate representational politics into (re)constructions of the past.

Michael Schaffer wryly remarks that:

thanks to Hughes and his colleagues, I knew exactly what to expect when I moved home [to the United States] at age 14. High school would be big and crucial; my standing in its hierarchy of jocks and brains and losers would determine my happiness. Like any true, red-blooded American kid, I knew I would care desperately about the football game, the dance afterwards, and the big, drunken party to follow. Hey - I'd watched the instructional video. ${ }^{45}$

Whilst Schaffer later admits that his high school experiences resembled little of the 'instructional' Hughes movies, the statement emphasises the currency of the films and the pedagogy of popular culture - the shared space of the high school where fantasy and reality collide in such a way that they become indistinguishable. The films work like animated high school year books, an anthology of collective memories. The excessiveness of intense moments in teendom - the ecstasy of the first kiss, the anxiety of graduation, fears of hallway bullyingare granted a mode for representation and interpretation through cinematographic techniques such as the intimacy of a close-up shot, the accompaniment of image with musical score and montage sequences. These moments are invested with a profundity and importance that cannot be adequately relayed by conventional historical documentation. Youth ceases to be simply a phase with 'she'll get over it' as the ultimate dismissive palliative. The problems and politics of youth are acknowledged as very real.

In Hughes' films a micro-politics is practised in which the high school functions as a microcosm of the wider social framework. The central agency is transferred from adults to 
adolescents and the traversal and dissolution of boundaries enables an ideal mobility and 'reconciliation of diverse bodies'. ${ }^{46}$ Here, the nerds can be hailed the heroes (Weird Science), the stifling bureaucracy as embodied by the pompous, vindictive principal can be subverted in the name of freedom (Ferris Bueller's Day Off) and the artistic recluse can befriend the most popular girl at school (Some Kind of Wonderful) ${ }^{47}$ Like the glorious pandemonium of the carnival, the boundaries between authority and the oppressed are transgressed. The malleability of the high school structure is a precursor of societal change. In a memorable scene from Pretty in Pink, Andie confronts Blane to discuss the senior prom. When she demands an answer as to whether he will escort her or not, he feebly mumbles that he had forgotten a previous engagement which is a blatant lie.

Andie: You're a liar. You're a filthy, fucking no-good liar! You don't have the guts to tell me the truth ... You're ashamed to be seen with me ... You're ashamed to go out with me. You're afraid. You're terrified your god damn rich friends won't approve!

Beating Blane against the locker, Andie is the vision of the frustration of the disempowered and in her rage she acts as a siphon of social truths. Prom politics becomes a point of reference for global politics. Meaghan Morris rightly states that culture has 'supplanted politics and religion as the dominant heading under which the social and moral issues of the day are played out'. ${ }^{48}$ In a decade of excessive consumption and capitalism, Pretty in Pink is an emotive purging and socio-political commentary of the times. Music and fashion are not just consumer products, but metaphysical skins grafted onto the body. It is significant that Andie dresses in clothing that layers the vintage over the modern. After having been stood up by her partner, she resolves to attend the prom solo as an act of self-empowerment to show that she has not been defeated. Her presence alone, however, is not enough. Andie's actual prom dress must speak words for her. She 'takes Iona's prom dress and the lurid pink gift from her father, and with her artistic bent, converts them into something that is less a garment than a statement: a cool, pink, fuck you, a sexy suit of armor'. ${ }^{49}$ The character's wearing of fragmented pop couture from various eras is derived less so from financial necessity than self determinism and agency. In this decade of meta-cultures, the past and present congeal into an eclectic bazaar of styles where in(ter)vention of commodity culture allows infinite possibilities for transformation and subversion. The originally designed prom gown is a hybrid creation of outdated, second-hand garments (one of which is clearly from the 1960s) that refuses to be comfortably categorised as definitively of the 1980s, or classically stunning. When Andie enters the grand ballroom in her home-made ensemble, the moment crystallises the oppressive class structure. More importantly, there is overwhelming pathos in the scene which acts like a snapshot in time that has not only been captured, but vicariously (and cathartically) experienced by the audience. 
The Ringwald phase of the 1980s carries such emotional gravity for the youth of then and now that the actor has transcended her own existence to become a rare phenomenon-an image that encapsulates a moment so deeply that it has literally shaped pop culture history and is crucial to how it is remembered by the youth of that era. Nostalgic strolls down the 1980s memory lane are traced through the trajectory of a Ringwald-Hughes plot like a geographical map. Molly Ringwald meant something more than just a teenage takeover of the multiplex. Popular culture, popular memories and fandom have grounded the actor's identity, fictional and real, in time and her place within it in which she is no longer just an abstraction of the 1980s. Molly Ringwald was the 1980s.

While popular remembrances of the actor ensure that she will not be forgotten or lose her iconic status, there is always the potential danger of inadvertently historicising memory. Where Molly Ringwald is now illuminates the trade-off for being heralded the model teen of an era. 'Ringwald's Fountain of Youth is laced with citric acid'. ${ }^{50}$ It is a stalemate that consigns her to reliving her teenage years over and over again. In an interview, Hughes commented in relation to the character of Ferris Bueller, 'You don't want to see him today. You'd hate him. He'd either be a bum or a politician. ${ }^{51}$ Ringwald, as with Matthew Broderick as Ferris, represents that transitory, but liminal, moment of optimism that the future holds unbounded potential before the disappointment of adulthood descends. The ephemerality of Ringwald's high school days are intentionally stretched; pulling her past over the present. In short, Ringwald had not only been type-cast but more significantly, she had been time-cast.

\section{- Homecoming QueEn: Back to SChool}

Ringwald's projects in recent years underscore her cauterisation in the 1980s in which she wears the decade like the scars of a third degree burn. In Teaching Mrs Tingle (1999), the actor portrays a timid administrative staff member at Grandsboro High School who converts into a farcically, foul-mouthed substitute teacher-appropriately for History class. In the Australian production Cut (2000), she is cast as a B-grade Los Angeleno soap actor. Fourteen years prior, Vanessa Turnbull starred as a teenage victim of a slasher film. Production was halted when a murder was committed during the film's shooting. The actor returns to fill in as the dead girl's mother, only to discover that the past has literally come back to haunt her as the killer is a paranormal phantom that materialises into corporeal form each time the original reel is revisited. Despite the film's black humour and Ringwald's acerbic impression of the diva which poked fun at her own infamous fiery temper, Cut failed commercially. It seemed the audiences were still not ready to see the actor grown up.

In arguably her most memorable part in recent years, Ringwald was required to return to high school. Not Another Teen Movie (2001) parodies the popular American teen films of the 1980s and 1990s, with particular reverence paid to the Hughes opus. Ringwald's cameo 
appearance as a Flight Attendant reflects upon her integral function within this discursive framework. At the film's climax, Jake (Chris Evans) attempts to convince Janey (Chyler Leigh) who is partially modelled on Ringwald's character of Andie Walsh-not to leave him for France where Ringwald defected to in 1992. Struggling to express his feelings, Jake plagiarises identifiable lines from other teen movies including Pretty in Pink, only to be reprimanded by Ringwald for his lack of originality and hyperbolic sentimentality. When the two lovers resolve their differences, ready for the kiss that will cue the rising swell of inspiring music and the credits, Ringwald's character cynically rebukes them. Directing her comments to the camera, she complains: 'We all know where this is going. Fucking teenagers.'

For that brief moment in time, Ringwald stepped out of the 1980s. The 'adult Molly' brought her present into the past, enabling her to resist time-casting as the perennial adolescent. In that transient window of opportunity, Ringwald's importance to youth culture, popular memory and middle America in the 1980s convene in a perfect synchronicity and clarity. The irony of knowing 'where this is going' was that she was never allowed to go beyond 'there'. It is relevant that Ringwald's much hyped role was to take place within borrowed plot lines from her Hughes projects where the school is called John Hughes High, and the cover track over the closing titles is 'Don't You (Forget About Me)' by Simple Minds— the song that was the anthem for The Breakfast Club.

Sandra Dee, the personality, only existed in and for the 1950s and 1960s. The person behind the mediated public image was superseded by the greater narrative of a myth. Her final performance would cast the last(ing) impression in popular culture of a still-life portrait, and homage to the dead. Molly Ringwald, however, has not experienced this finale. She continues to have a strong presence in the entertainment industry; moving from the 1980s, through the 1990s and into the twenty first century. While her impressive performances in post-Hughes productions have garnered critical attention and acclaim, for instance her role as Frannie Goldsmith in the 1994 television mini-series The Stand and the brazen Sally Bowles in the Broadway production Cabaret in 2001-2002, the past maintains an uneasy stranglehold over her. Reviews and articles tend to hark back to Ringwald's Hughes heydays in much the same way we cannot resist forlornly reminiscing about a once-brilliant child prodigy who has stepped into mediocrity in adulthood; signifying a loss that is both theirs and ours. Ringwald resists this inertia; always chasing the dream of social mobility. We loathe to release Ringwald into the world beyond graduation because the dream of that 1980s is not yet ready to be over. A critical examination of nostalgic and populist memories of this actor reveals our complicity in her time-casting and forces a reflective gaze upon the self. Whom we yearn for provides an intimation as to what we long for. While Samantha Baker, Claire Standish and Andie Walsh are tactically remembered as the darlings of a decade, Molly Ringwald herself may as yet hitch that elusive ride back to the future. 
Betsy's Wedding (1990), Alan Alda

Breakfast Club, The (1985), John Hughes

Cut (2000), Kimble Rendall

Ferris Bueller's Day Off (1986), John Hughes

For Keeps (1988), John G. Avildsen

Fresh Horses (1988), David Anspaugh

King Lear (1987), Jean Luc-Godard

Less Than Zero (1987), Marek Kanievska

National Lampoon's Animal House (1978), John Landis

Not Another Teen Film (2001), Joel Gallen

Pick Up Artist, The (1987), James Toback

Porky's (1982), Bob Clark

Pretty in Pink (1986), Howard Deutch

Rebel Without A Cause (1955), Nicholas Ray

Sixteen Candles (1984), John Hughes

Some Kind of Wonderful (1987), Howard Deutch

Stand, The (1994), Mick Garris

Teaching Mrs Tingle (1999), Kevin Williamson

21 Jump Street (1987), Patrick Hasburgh and Stephen J. Cannell (creators)

Wall Street (1987), Oliver Stone

Weird Science (1985), John Hughes

I would like to thank Dr Kara-Jane Lombard, Josephine Lee and the anonymous reviewer for their constructive feedback provided on an earlier draft of the paper.

CHRISTINA LEE is a lecturer in Media and Cultural Studies at Curtin University of Technology. She has published in the areas of youth cinema, contemporary Chinese cinema, popular culture and terrorism. She is currently writing a book on the iconography of Generation X in film and editing an anthology on history, memory and nostalgia in cinema.<c.lee@exchange.curtin.edu.au>

1. Simple Minds, 'Don't You (Forget About Me)', Virgin Records Ltd, 1985.

2. Richard Corliss, 'Well, Hello Molly! Meet Hollywood's New Teen Princess', Time, vol. 127, no. 21, 26 May 1986, p. 67.

3. Popular Memory Group, 'Popular Memory: Theory, Politics, Method', in Richard Johnson et al (eds), Making Histories, University of Minnesota Press, Minneapolis, 1982, p. 243.
4. David Lowenthal, The Past is a Foreign Country, Cambridge University Press, Cambridge, 1985, p. 234.

5. Zygmunt Bauman, 'Space in the Globalising World', Theoria, June 2001, p. 17.

6. Greil Marcus, The Dustbin of History, Harvard University Press, Cambridge, 1995, p. 17.

7. Richard Dyer, Stars, British Film Institute, London, 1998 (1979), pp. 2-3. 
8. Popular Memory Group, p. 207.

9. Patrick Wright, A Journey Through Ruins, Flamingo, London, 1992, p. 357.

10. Lowenthal, p. 228

11. Popular Memory Group, p. 240

12. Andreas Huyssen, Twilight Memories: Marking Time in a Culture of Amnesia, Routledge, New York and London, 1995, p. 3.

13. Raphael Samuel, Past and Present in Contemporary Culture. Volume 1 of Theatres of Memory, Verso, London and New York, 1994, pp. ix-X.

14. Marcus, p. 13

15. Judy Giles, 'National Countermemories: Narratives of Gender, Class, and Modernity in Women's Memories of Mid-Twentieth Century Britain', Signs: Journal of Women in Culture and Society, vol. 28, no. 11, 2002, p. 24.

16. Popular Memory Group, p. 205.

17. Giles, p. 24

18. Svetlana Boym, The Future of Nostalgia, Basic Books, New York, 2001, pp. 41, 49.

19. Boym, pp. 49-50.

20. While Ringwald had been performing since early childhood, it was Sixteen Candles which put her in the Hollywood limelight as a starlet.

21. John Hughes quoted in Corliss, "Well Hello Molly!', p. 67.

22. Stephen Tropiano, Rebels and Chicks: A History of the Hollywood Teen Movie, Back Stage Books, New York, 2006, p. 177.

23. Timothy Shary, Teen Movies: American Youth On Screen, Wallflower, London and New York, 2005 , p. 71

24. Adrian Martin, Phantasms: The Dreams and Desires at the Heart of Our Popular Culture, McPhee Gribble Publishers, Victoria, 1994, p. 67. Corliss, 'Well Hello Molly!', p. 67.

25. Pauline Kael quoted in Michael Agger, 'Don't You Forget About Me', New York Magazine, 6 December 2004, <http://www.newyorkmetro.com/nymetro/ arts/theater/10522/>

26. Dyer, p. 98

27. David Hutchings, 'Molly Ringwald Goes to the Head of the Teen Class with Pretty in Pink, but She'd Rather Play Grown-Up', People Weekly, vol. 25, no. 12, 24 March 1986, p. 87.

28. People Weekly, 'Molly Ringwald: Townies', People Weekly, vol. 46, no. 10, 2 September 1996, p. 48.

29. Motion Picture Herald quoted in Thomas Doherty, Teenagers and Teenpics: The Juvenilization of American Movies in the 1950s, Temple University Press, Philadelphia, 2002, p. 160.

30. Sandra Dee, 'Learning to Live Again', People Weekly, vol. 35, no. 10, 18 March 1991, pp. 87-94.

31. Georganne Scheiner points out that the Tammy films which propelled Dee into the public eye as an innocent were not representative of a career in which the actor was portrayed, more often than not, as a problematic youth with sexual innuendo inflected in her performances. See: Georganne Scheiner, 'Look At Me, I'm Sandra Dee: Beyond A White Teen Icon', Frontiers, vol. 22, no. 2, 2001, pp. 87-106.

32. Roland Barthes, Mythologies, trans. Annette Lavers, Jonathon Cape, London, 1972 (1957), p. 129

33. Barthes, p. 143

34. Boym, p. 78.

35. Giorgio Agamben, Infancy and History, Verso, London, 1993, p. 99

36. Carl M. Cannon, 'The ' 80 s vs. the ' 90 s', National Journal, vol. 32, no. 16, 15 April 2000, p. 1189.

37. 21 Jump Street was created by Patrick Hasburgh and Stephen J. Cannell for Fox Studios. The program was first aired on 12 April 1987 (in the US) and ran for five seasons

38. Sarah Hentges, Pictures of Girlhood: Modern Female Adolescence on Film, McFarland and Company, Jefferson NC and London, 2006 , pp. 42-43.

39. Jim Leach quoted in Jon Lewis, The Road to Romance and Ruin, Routledge, New York and London, 1992, p. 139 [italics in original text].

40. Giles, p. 24

41. Stewart Brand, The Clock of the Long Now, Basic Books, New York, 1999.

42. Lisa Roberts, From Knowledge to Narrative Smithsonian Institution Press, Washington, 1997, p. 135

43. Agamben, p. 17

44. Jon Savage, Time Travel, Vintage, London, 1997, p. 2

45. Michael Schaffer, 'No More Fast Times at Ridgemont High', The Washington Monthly, January 2001, p. 28

46. Lesley Speed, 'Pastel Romances: The Teen Films of John Hughes', Metro, no. 113/14, 1998, p. 104.

47. Although Howard Deutch directed Pretty in Pink and Some Kind of Wonderful (which Hughes wrote), Hughes is still credited as the auteur of these films.

48. Personal communication with Meaghan Morris (21 May 1997). Mark Davis, Gangland: Cultural Elites and the New Generationalism, Allen and Unwin, St Leonards, 1997, p. 30.

49. Jonathan Bernstein, Pretty in Pink: The Golden Age of Teenage Movies, St. Martin's Griffin, New York, 1997, p. 77

50. Richard Corliss, 'Growing Pains: Pretty in Pink', Time, vol. 127, no. 9, 3 March 1986, p. 83

51. John Hughes quoted in David Daley, 'How Could We Forget?', The Fargo Forum, 8 April 1999 , <http://www.mollyringwald.co.uk/article2.html>. 